\title{
Iraq, 9/11, and the Mediated Presidency of George W. Bush
}

\author{
Stephen J. Farnsworth and S. Robert Lichter
}

George W. Bush’s presidency has been marked by aggressive media management efforts that have generated mixed success. This article examines how Bush and his White House media team sought to manage the media largely by framing the president primarily as a wartime commander-inchief. This article discusses the administration's media strategies designed to secure more positive news coverage and employs a content analysis of network news coverage of Bush during key periods of his presidency to examine their effectiveness. The findings demonstrate that the White House enjoyed relatively positive news coverage in the months after September 11, 2001 and during the combat phase of the 2003 U.S.-led invasion of Iraq. At many other times during his presidency, though, the Bush tendency to over-promise led to highly critical news coverage. As the distance from 9/11 increased, the tone of coverage turned increasingly negative.

Presidents have long used the mass media to try to gain public support for themselves and their favored policies, and the 24/7 nature of modern cable and internet news has greatly increased the opportunities for presidents to spin the news to their advantage. This expanded range and volume of mass media came about during a period of narrowly divided U.S. presidential politics. The 2000 presidential election, the first open-seat contest for the White House of the internet age, and the manner by which Bush emerged victorious-including what many citizens viewed as dubious vote-counting procedures in Florida and a partisan 5-4 ruling by the Supreme Courtincreased the need for the new president to sell his presidency and himself to a deeply divided country (Dimock 2004; Nelson 2003; Pfiffner 2004a, 2004b). Unfortunately for Bush, the same expanded news environment that gave the White House new opportunities to try to influence the public agenda offered his critics new media vehicles as well (Farnsworth 2009; Hall 2001).

The authors thank George Mason University and the Center for Media and Public Affairs for financial support and Graham Dodds for his helpful suggestions. All errors and interpretations remain the authors' responsibility. Please direct all comments and correspondence to Stephen Farnsworth, Department of Communication, George Mason University, Thompson Hall, Room 212, 4400 University Drive, MS 3D6, Fairfax, VA 22030, Phone: (703) 993-4122, Email: sfarnswo@gmu.edu.

STEPHEN J. FARNSWORTH is an assistant professor of communication at George Mason University. S. ROBERT LICHTER is a professor of communication at George Mason University and the President of the Center for Media and Public Affairs.

The American Review of Politics, Vol. 29, Winter, 2008-2009: 331-350

(C)2008 The American Review of Politics 
This article examines the key media management strategies employed during the Bush presidency. After a discussion of those approaches, content analysis of network television news reports will be employed to determine the effectiveness of administration efforts to manage the news to its advantage and how Bush's performance compares to his predecessors.

\section{The Permanent Campaign and "Going Public"}

For the past half century, nearly every presidential team continued to campaign after it was in the White House, trying to sell the president in the same way it previously had sold the candidate (Tulis 1987). This practice of governing through a permanent campaign offers mixed results. On the positive side, continuing White House solicitation of public support makes politics more focused on public opinion (and less elite-driven) than it was in the days before television and the Internet (Waterman, Wright, and St. Clair 1999). More negatively, presidential marketing may trump substance in the process of lawmaking, favoring short-term benefits over long-term oneseven when the eventual costs outweigh the benefits (Miroff 2006). In addition, the modern media environment encourages presidents to overpromise, leading to deep citizen frustration when results do not live up to expectations (Cronin and Genovese 2004; Lowi 1985).

The rise of radio, the first national mass media, helped create presidency-dominated politics. Franklin Delano Roosevelt used the new technology to be heard in living rooms around the country (Burns and Dunn 2001). Television, an even more powerful technology, gave his successors great opportunities to shape the public agenda and create favorable personal images.

While television and the Internet convey immense communication advantages to the White House, presidents have not always been as effective as they might have been in marketing their policies or themselves (Brody 1991; Cook 2002; Gilbert 1989; Gregg 2004; Han 2001; Kurtz 1998). Although presidents may not always convince Congress, the citizenry, or the governments of other nations to view a White House policy proposal as they do, chief executives can do far more to shape public discourse than can any other political actor (Kernell 2007; Tulis 1987).

Academic studies of media coverage of the federal government repeatedly have confirmed the news media's intense focus on the executive branch. Presidential actions are also more definite than the incremental developments on Capitol Hill, where nearly every bill fails to clear the cumbersome lawmaking system (Mann and Ornstein 2006). Given the much greater public awareness of presidents and their greater ability to have the last word, it is no wonder that the White House receives far more coverage 
than Congress, and has done so throughout the television age (Graber 2006; Grossman and Kumar 1981; Hess 1981, 1986, 1991, 1996; Lichter and Amundson 1994; Lowi 1985; Waterman, Wright, and St. Clair 1999).

In fact, the White House news coverage advantage is overwhelming. Using content analysis consisting of careful line-by-line dissection of news reports, researchers have found that presidents routinely receive 70 percent or more of news coverage of government (Graber 2006). One study that looked at the entire content of the evening newscasts of ABC, CBS, and NBC for the first years of the presidencies of Ronald Reagan (1981), Bill Clinton (1993) and George W. Bush (2001) found that the executive branch received 76 percent of all government coverage in 1981, 88 percent in 1993, and 82 percent in 2001. In the best year for the legislative branch of those three examined in that study, Congress was out-covered by the executive branch on television by roughly a four-to-one margin (Farnsworth and Lichter 2006). The same patterns of executive branch media dominance are seen when comparing the sources quoted on network newscasts (Farnsworth and Lichter 2006, 39). As a result, when Americans turn to the mass media to try to follow national policy debates, the perspective offered is more the view from the White House than from Capitol Hill (Rozell 1994).

Given these structural advantages favoring the White House, the Bush administration relied on a variety of media management approaches previously employed by recent presidents. Above all, presidential teams avoid full disclosure of an administration's shortcomings. But consistently unrealistically optimistic portrayals of policies undermine the believability of the White House spin, creating a troubling credibility gap between the actual reality and what the government maintains is the reality (Kumar 2001; Nelson 2003). After leaving office, former Bush press secretary Scott McClellan (2008) lamented the aggressive political propaganda campaign that he said he helped engineer to promote the Iraq war.

Administration officials try to use the media to showcase the president, highlight the most important issues, and draw attention to administration accomplishments. These efforts also are designed to improve the president's standing in public opinion polls, which is particularly important if an election or a controversial policy debate is in the offing (Kumar 2001, 2003). They also try to downplay negative stories and to try to shift blame away from the president by sending reporters to the agencies for bad news (Shane 2007c). Bush was better off when the Federal Emergency Management Agency (FEMA) was made the most visible point of contact with reporters for the government's response to Hurricane Katrina, which devastated New Orleans and much of the Gulf Coast during 2005. (But that worked only briefly. Bush eventually went to New Orleans to take personal charge of the 
situation — and to try to turn around the negative news coverage of FEMA's response to the disaster.)

The presidential strategy of moving Congress by first persuading citizens to support the president is known as "going public," a common media campaign strategy employed by all recent administrations (Kernell 2007). The modern media environment forces presidents to promote their policies publicly, if for no other reason than that a president's opponents will be using media strategies to undermine support for White House initiatives. A president who does not go public runs the risk of appearing weak (Kernell 2007).

Some scholars, most notably political scientist George Edwards (2003, 2004, 2006), believe that presidents accomplish little by going public, and in fact may even make things worse by trying to legislate through the mass media. President Bush's key second term domestic priority—partial privatization of Social Security - failed to generate enthusiasm among citizens or the Republicans who controlled 109th Congress (Edwards 2006). Bush's efforts to sell his international initiatives did not fare well either, according to Edwards. By mid-2006, roughly two-thirds of Americans thought that Iraq was not connected to the war on terror, despite many Bush administration claims of a link between Saddam Hussein and 9/11. In addition, Bush's own efforts to sell himself as a competent and visionary leader also fell short, and his approval numbers sank throughout most of his second term and his party suffered a crushing defeat in the 2006 midterm elections (Balz and Cohen 2006; Broder 2006; Nagourney and Elder 2006a, 2006b).

\section{The Key Elements of Managing the Media, Bush-style}

Above all, the Bush Administration's media management style, post 9/11, focused on presenting the president as a war-time commander-in-chief. Although his first remarks on that fateful day were uneven, the new president clearly found his voice at Ground Zero a few days later when he shouted into a bull-horn: "I hear you. The rest of the world hears you. And the people who knocked these buildings down will hear all of us soon" (Frum 2003, 140). The U.S. public routinely rallies around the president in times of crisis, and the terrorist attacks triggered a massive increase in Bush's public approval ratings, rising from 51 percent to 86 percent in less than a week (Nelson 2003). Those high approval ratings led to considerable legislative branch deference on matters that would otherwise have been nearly impossible to pass, including the Iraq Resolution of 2002 and the PATRIOT Act of 2001 (Baker 2002; Kassop 2003; Lindsay 2003).

Bush took World War II as his media image for the war on terror. The terrorist attacks of 9/11 were presented as the Pearl Harbor of a new genera- 
tion, and the term axis of evil recalls the Axis powers of World War II. With this comparison, Bush hoped to recreate a time when Americans came together in rare unity to defeat their enemies. In addition, the administration routinely portrayed Bush's goals as crises in order to maximize both media attention and the chances that Bush's preferences would be followed (VandeHei 2005).

The administration said the pivotal issue of the 2002 midterm elections was the looming Iraq war. Congress must, Bush insisted in speeches on behalf of Republican candidates, make a decision on whether to authorize force before the election. Because the 2002 elections occurred only fourteen months after 9/11, Bush's claims that Saddam Hussein was connected to those terrorist attacks and that he was building a nuclear weapons program were powerful arguments. Also, because the Pentagon and the Central Intelligence Agency (CIA) are part of the executive branch, little information emerged to undermine the president's story-even though the nation later learned that many government experts rejected Bush's conclusions (Entman 2004). Republicans were able to attack as soft on defense those Democrats who objected or even hesitated to pass Bush's resolution (Fisher 2004). From a military standpoint, there was little need to rush the vote. Bush did not start the war until March 2003, more than four months after the 2002 midterms. From a political standpoint, forcing a preelection vote helped the GOP defeat some Democratic incumbents.

Bush likewise used the war in Iraq and appeals to patriotism to secure his own reelection in 2004, regularly campaigning at rallies held with the troops during that campaign (Ceaser and Busch 2005). The vacillations of U.S. Senator John Kerry (D-MA), the 2004 Democratic nominee, on how he felt about the war he had earlier voted to authorize helped Bush win a second term (Easton et al. 2004). But there are limits to presidential spin, particularly over time. The undeniable problems of the Iraq occupation made the war a negative factor for Republicans in the midterm elections two years later (Broder 2006; Milkis 2006).

Bush's team worked diligently to control what the legislative branch, reporters, and the public knew by refusing to release information requested by Congress. Republican majorities generally blocked Democratic efforts to obtain information, and Democratic majorities were routinely ignored by an administration making expansive claims of executive privilege (Lichtblau 2007; Mann and Ornstein 2006). Many of these legal disputes lasted beyond the Bush presidency.

Because the administration has access to far more national security information than does anyone on Capitol Hill, lawmakers must think twice before challenging the White House over an alleged military threat. U.S. Senator Max Cleland (D-GA), a skeptic of Bush's decision to wage war in 
Iraq before capturing Osama bin Laden, was defeated in 2002 in a campaign marked by advertising that featured Cleland's face morphing into that of bin Laden. For years, Cleland's defeat reminded legislators of the administration's power to crush opponents. Even after public sentiment shifted, Democratic lawmakers hesitated to mount a coherent legislative challenge to the unpopular president's unpopular foreign policies (Risen and Lichtblau 2007).

Administration counterattacks were also leveled against other voices, including former U.S. Ambassador Joe Wilson, who determined that administration claims regarding Iraq's acquisition of atomic weapons materials in Niger were bogus, and Army Chief of Staff General Eric Shinseki, who told Congress before the war started that the occupation of Iraq would require nearly twice as many troops at the White House claimed (Johnston and Rutenberg 2007; Shane 2007c; Shanker 2007). For his honest assessmentrequired by law in congressional testimony-Shinseki was "permitted" to retire early (Shanker 2007).

Bush administration statements to reporters to discredit Wilson and his wife, Valerie Plame, a CIA officer, led to the conviction of Scooter Libby, a top Cheney aide, for perjury over the matter (Shane and Lewis 2007). Libby's trial revealed extensive details of administration efforts to influence Washington reporters and to discredit Wilson and other naysayers by spinning off-the-record tales to favored reporters (Johnston and Rutenberg 2007; Shane 2007c).

The Bush administration, like its predecessors, rewarded reporters who produced stories that placed the president in a good light and punished more critical reporters by denying them leaks (Kurtz 1994, 1998). The wide range of media outlets found online make it even easier for government officials to play favorites and provide ideal vehicles for attacking mainstream media outlets as reflexively anti-Bush (Mooney 2004; Rutenberg 2006).

Traditional media sources can also be of use. Judith Miller, a national security correspondent for the New York Times, was a favored conduit for information that the Bush team wanted to make public to help build the case for the Iraq War. A subsequent internal Times investigation condemned the paper's performance, saying reporters and editors did not scrutinize the Bush administration's pre-war claims aggressively enough (Kurtz 2007; Orkent 2004).

Rose-colored scenarios are a common presidential media tactic. The Bush administration also used the media to predict that the benefits of the Iraq war would be great and the costs would be minimal, and soon would be covered by Iraqi oil revenues (Gordon 2003; Rieff 2003). After a quick occupation, Bush predicted Iraq would rapidly become a peaceful, stable democracy, serving as a model for the region. Other presidents have done 
the same. More than two decades earlier, Ronald Reagan sold his tax cuts based on estimates of economic growth and revenue expansion that turned out to be false (Quirk 2006). Critics charged that Clinton also underestimated the costs of the 1994 health insurance bill (Skocpol 1997).

The Bush administration closely followed the lead of other presidencies when it came to focusing on the importance of word selection and definition. Although President Bush said the U.S. military did not torture its prisoners, Bush refused to define the term publicly. When Congress passed a law banning torture, Bush signed it and said the U.S. government would not torture-but again, as he defined the word (Shane and Liptak 2006; Zernike 2006). The administration again refused to state publicly what constitutes torture, and even key allies such as the United Kingdom fault the United States for continuing to torture suspects (Bonner and Perlez 2007). During the 2006 midterm elections Bush claimed the administration was committed to "staying the course" in Iraq, but after the midterms Bush revealed that the administration actually had been planning a major troop escalation, called a “surge” (Burns, Tavernise, and Santora 2007; Rutenberg and Cloud 2006).

Bush was hardly the first president to resort to word-play to accomplish an objective. In 1998, for example, Bill Clinton issued his forceful denial of an affair with Monica Lewinsky: "I did not have sexual relations with that woman," he exclaimed. As was later discovered in Kenneth Starr's investigation, Clinton defined sex as intercourse and excluded oral sex from his definition (Berman 2001; Isikoff 2000; Klein 2002). Likewise, Richard Nixon said in his 1968 campaign that he had a "secret plan" to end the war. But his real secret was that there was no such plan, though that fact became clear only after Nixon took office (Dallek 2007).

There are limits to news management by Bush or any other president. Above all, many events are outside presidential control. Even as Bush sought to divert attention away from bin Laden and toward Saddam Hussein in 2002 and 2003, bin Laden frequently returned to the public eye with new videotapes warning of future attacks. Although those commentaries generally became only brief news snippets, for a while they undermined the administration's efforts to get the public to concentrate on Iraq. But Bush's intense focus on Iraq, and his "Mission Accomplished" appearance on an aircraft carrier in mid-2003, backfired when the occupation proved far more violent than promised (Chandrasekaran 2006; Milbank 2004). Likewise, as the "surge" seemed to improve conditions in Iraq during 2008, Bush's poll numbers did not recover (Farnsworth 2009). Instead, public attention turned towards domestic policy matters, including bank failures, stock market declines, and housing crises. 


\section{The Data}

In this study we use content analysis to examine the tone of coverage of network news stories that covered President Bush. We examine coverage of Bush during several distinct periods of his presidency: the entire first year (2001) that Bush served as president (with separate breakdowns for before and after 9/11 as well as for Bush's first 100 days in office), news coverage during the active combat phase of the Iraq war (March 19 through April 30, 2003), the first six months of the Iraqi occupation (May 1 through October $31,2003)$, coverage of Bush during the first 100 days of his second term in 2005, as well as coverage during March and April of both 2005 and 2006. These time periods create rough trajectories of news coverage at key points across the Bush presidency and include periods of combat and of occupation.

These news reports are content analyzed by the Center for Media and Public Affairs, a nonprofit and nonpartisan research organization. The data utilized here are part of a database of more than 16,000 content analyzed network news stories reporting on recent presidencies. (Financial considerations prevented a content analysis of news coverage of the entire Bush presidency). Where available we compare coverage of Bush with that of three recent predecessors: Bill Clinton, George H.W. Bush, and Ronald Reagan.

Content analysis is a technique that allows researchers to classify statements objectively and systematically according to explicit rules and clear criteria. The goal is to produce valid and reliable measures of program content. Other investigators who apply similar procedures to the same material should obtain similar results. With content analysis, clear rules and standards are set for identifying, measuring, and classifying each news story.

Our analysis is based primarily on individual statements or sound bites within each story. Although time-consuming and labor intensive, this sentence by sentence analysis allowed us to analyze the building blocks of each story separately, rather than making summary judgments of entire stories. Instead of coding an entire story as "positive" or "negative" toward an individual or institution, we coded each evaluation within the story for its source, topic, object and tone. A single story might contain several evaluations of various actors; our system captured each one individually. This procedure produces a very detailed picture of the news media's treatment of government. We argue that our approach creates a more accurate result than coding at the story level, where there may be more disagreement among coders.

Evaluations were coded as positive or negative if they conveyed an unambiguous assessment or judgment about an individual, an institution, or an action. Only explicit evaluations were coded, in which both the target of 
the evaluation and its direction were clear. We only analyze evaluations made by nonpartisan sources, who are likely to be taken more seriously than the often-predictable talking points offered by explicitly partisan voices (cf., Farnsworth and Lichter 2006). A description of events that reflected well or badly or some political actor was not coded for tone unless it contained an evaluative comment. For example, an account of the passage of an administration-supported bill would be coded as positive only if a source or reporter explicitly described it as a victory for the White House, a validation of the president's views or efforts on its behalf, etc. (Intercoder reliability for each measure used here exceeds .80.)

In recognition of the increasingly important role played by the latenight comics in helping shape the country's political discourse, we also examine the subject of the more than 20,000 late night jokes told by comedians since 1989.

\section{Results}

Turning first to the comparison of the Bush presidency over time, we see in Table 1 the extent to which George Bush has received overwhelmingly negative news coverage during many parts of his presidency. Presidential efforts to spin the news were most effective in the immediate aftermath of 9/11, when coverage of Bush was 63 percent positive in tone (because we report only clear directional expressions of tone, the above figure also means that tone was negative 37 percent of the time). The second highest period of coverage of Bush we examined here was during the combat phase of the Iraq war, when coverage was 49 percent positive.

The two periods of 2003 demonstrate how quickly a president's fortunes can change. During the first six months of the Iraqi occupation, which started after the "Mission Accomplished" appearance on the USS Lincoln, coverage was only 31 percent positive in tone. Declaring an end to major combat operations, as Bush did that day, appeared to trigger a return to more normal conditions in media coverage, when the commander-in-chief becomes more of a civilian political actor, and more subject to criticism from reporters and their sources.

As the promises of Iraq's rapid democratization gave way to a long, violent slog, reporters were increasingly critical in their coverage of Bush. During March and April of 2005 and 2006, when attacks on U.S. troops were common, coverage of Bush was more negative than positive by a threeto-one margin. Bush himself, in interviews with Washington Post journalist Bob Woodward, has argued that he has been subject to an unusually harsh treatment by reporters and members of the Washington community quoted 
Table 1. Tone of Coverage of Bush Over Time (ABC, CBS, NBC evening newscasts)

\begin{tabular}{lc}
\hline Time Period & Percent Positive \\
\hline 2006 (March 1 - April 30) & $24 \%$ \\
2005 (March 1 - April 30) & $21 \%$ \\
2005 (Jan. 20 - April 29) & $33 \%$ \\
(First 100 Days 2nd Term) & \\
2003 (May 1 - October 31) & $31 \%$ \\
(six months after “Mission Accomplished”) & \\
2003 (March 19 - April 30) & $49 \%$ \\
(combat phase of Iraq war) & \\
2001 (full year) & $39 \%$ \\
& \\
2001 (post 9/11) & $63 \%$ \\
2001 (pre 9/11) & $36 \%$ \\
& \\
2001 (Jan. 20 - April 29) & $29 \%$ \\
(First 100 days 1st term) & \\
\hline $\begin{array}{l}\text { Note: Only sources not identified as partisan are included in calculations. } \\
\text { Source: Center for Media and Public Affairs. }\end{array}$ & \\
\hline
\end{tabular}

by those same reporters (Woodward 2008). Tables 2 and 3 examine the similarities and differences of news coverage over time, including the key wartime periods of the Bush presidency and his two most recent predecessors.

As discussed earlier, Bush's media team expanded upon many of the news management strategies of his predecessors. But they generally did not generate better press for their boss than that received by previous presidents. As shown in Table 2, the tone of coverage of George W. Bush on the three television networks during his first year was almost equally as positive (and as negative) as Bill Clinton's first year in 1993 and Ronald Reagan's first year in 1981. No partisan bias appears here. In fact, the most positive presidential first year was that of George H.W. Bush in 1989, when presidential news coverage was 55 percent positive in tone. Of course the elder president Bush came to office after serving as a vice president and followed a president from his own party. All three other examples here involve very different circumstances: partisan transfers of power to a president from outside Washington. 
Table 2. Tone of Coverage, First Year and First 100 Days (ABC, CBS, NBC evening newscasts)

\begin{tabular}{llc}
\hline First Year & & Percent Positive \\
\hline George W. Bush & 2001 & $39 \%$ \\
Bill Clinton & 1993 & $38 \%$ \\
George H.W. Bush & 1989 & $55 \%$ \\
Ronald Reagan & 1981 & $36 \%$ \\
\hline First 100 Days & & Percent Positive \\
\hline George W. Bush & $2005 *$ & $39 \%$ \\
George W. Bush & 2001 & $29 \%$ \\
Bill Clinton & 1993 & $41 \%$ \\
Ronald Reagan & 1981 & $43 \%$ \\
*First 100 days of a second term & & \\
Note: Only sources not identified as partisan are included in calculations. \\
Source: Center for Media and Public Affairs. \\
\hline
\end{tabular}

Turning now to the comparison of the first 100 days of new presidents, one does see larger tonal differences. George W. Bush had the most negative news treatment of the first 100 days of the recent presidents we examined, with news coverage that was positive only 29 percent of the time. Ronald Reagan's first 100 days and Bill Clinton's first 100 days received similar media reviews, with coverage that was 43 percent positive and 41 percent positive respectively. (Coverage of Bush's first 100 days of his second term was more in line with that of previous presidents, with news reports that were 39 percent positive in tone.)

Of course, Bush's presidency began in the wake of one of the most controversial presidential elections ever, one plagued by allegations of voter intimidation and voter suppression in Florida and settled only by a contentious 5-4 Supreme Court decision (cf., Dimock 2004; Tapper 2001, 2002). Given this backdrop, the unusually negative tone of early 2001 seems more likely to stem from the extreme circumstances of 2000 rather than an antiBush bias in the media. In fact, the overall numbers for 2001 as a whole suggest that the Bush team had some successes in spinning media coverage in a less negative direction as the year progressed.

Table 3 compares the coverage of recent presidents during several recent periods of military hostilities, when administration news content seems likely to be greatest. Indeed, the period following 9/11 was the most 
Table 3. Tone of Coverage of Presidents during Military Action (ABC, CBS, NBC evening newscasts)

\begin{tabular}{clc}
\hline & & Percent Positive \\
\hline George W. Bush & $\begin{array}{l}\text { 2003 Iraq, early occupation } \\
\text { (May 1 - October 31) }\end{array}$ & $32 \%$ \\
George W. Bush & $\begin{array}{l}\text { 2003 Iraq, combat phase } \\
\text { (March 19- April 30) }\end{array}$ & $49 \%$ \\
George W. Bush & $\begin{array}{l}\text { 2001 terrorist attacks } \\
\text { (September 11 - November 19) }\end{array}$ & $64 \%$ \\
Bill Clinton & $\begin{array}{l}\text { 1999 Kosovo Crisis } \\
\text { (March 24- May 25) } \\
\text { George H.W. Bush }\end{array}$ & $\begin{array}{l}\text { 1991 Persian Gulf War } \\
\text { (January 17 - February 27) }\end{array}$ \\
& $56 \%$ \\
Note: Only sources not identified as partisan are included in calculations. \\
Source: Center for Media and Public Affairs.
\end{tabular}

positive period of news coverage for the five periods examined here. Coverage of George W. Bush during the roughly two-month period after the terrorist attacks was 64 percent positive in tone, far more positive the tone Bush faced during his entire first year. News coverage during that period was also much more positive than during the six-week combat phase of the Iraq war in 2003 (49 percent positive) and the first six months of the U.S.led occupation of Iraq starting May 1, 2003 (32 percent).

The coverage differences for George W. Bush track closely his public opinion numbers, which skyrocketed after 9/11, increased again during the combat phase of the Iraq war, and started a significant decline as the occupation grew more challenging than expected (Farnsworth 2009). In the Washington Post/ABC News polls, Bush reached a high of 92 percent approval in October 2001, a few weeks after the terrorist attacks. His poll numbers spiked again during the Iraq war, reaching 77 percent approval in April 2003, as U.S. troops fought their way into Baghdad, and fell to a low of 56 percent approval in September 2003 (Farnsworth 2009, 27-29). During most of Bush's second term, the numbers were far lower: the president did not reach 50 percent approval in any of those polls after March 2005 and by his final year in office Bush was consistently opposed by at least two-third of the electorate (Farnsworth 2009, 27).

All presidents seem to have better press when military action is underway. Bill Clinton never ordered a military action on anything approaching 
the scale of the Iraq war. The largest military matter he faced was the Kosovo crisis of 1999. Unlike the other examples examined here, the Clinton administration's military response to that humanitarian and military crisis involved air strikes and not the use of ground troops. Not a single U.S. military serviceman or servicewoman died in those airstrikes, the most extensive period of Clinton's presidency when he functioned most clearly as commander-in-chief. The tone of news about U.S. involvement in the Kosovo crisis was only slightly less positive than George W. Bush's coverage after $9 / 11$.

The first Persian Gulf War, launched by George H.W. Bush in 1991, also triggered very positive news reports. Network news coverage during that five week campaign to dislodge Saddam Hussein from Kuwait was 56 percent positive. Both the 1991 liberation of Kuwait and the 1999 attacks on Kosovo enjoyed far more support in western capitals than Bush's 2003 war, minimizing negative comments from international leaders (Farnsworth and Lichter 2006).

Despite frequent White House criticism about hostile news coverage, the entertainment media may be the most resistant to presidential spin. Late night comedians and their views on the news have become key alternatives to obtain information about current events, particularly for younger voters (Pew 2000). For Bush entertainment news was bad, as shown in Table 4. For five straight recent years (from 2002 through 2006), George W. Bush was the butt of more jokes on these late night talk shows than any other political or cultural figures. (We do not yet have data for the jokes of 2007). In some years, including the year of the 2006 midterm election, Bush was the subject of more than twice as many jokes as the runner-up. The grilling of the president in these entertainment media was unrelenting. In 2001, the year of the terrorist attacks, Bush finished second in the late-night joke-off behind his predecessor.

Indeed, for Bill Clinton, who left office in January 2001 but has remained in the public limelight ever since, the results were particularly negative. For 15 straight years, including years before and after his eight years as president, Bill Clinton has finished first, second, or third in the number of jokes told about him. Clinton finished first seven times (including 2001, the year he left office), finished second five times and third in three other years. The first president Bush, in contrast, did not remain a leading focus of political humor after he left office.

George W. Bush now has endured a "winning" streak of seven years where he finished in the top three, but he lags far behind Clinton's late night humor record. 
Table 4. Political Humor of Late Night Television Comedians

\begin{tabular}{|c|c|c|c|}
\hline $\begin{array}{l}\text { Top Joke Targets } \\
\text { by Year }\end{array}$ & First & Second & Third \\
\hline \multicolumn{4}{|l|}{ George W. Bush } \\
\hline 2006 & G.W. Bush 1213 & Dick Cheney 430 & Bill Clinton 195 \\
\hline 2005 & G.W. Bush 544 & Michael Jackson 413 & Bill Clinton 115 \\
\hline 2004 & G.W. Bush 1170 & John Kerry 505 & Bill Clinton 320 \\
\hline 2003 & G.W. Bush 374 & Bill Clinton 241 & Schwarzenegger 153 \\
\hline 2002 & G.W. Bush 311 & Bill Clinton 190 & Martha Stewart 91 \\
\hline $2001 *$ & Bill Clinton 657 & G.W. Bush 546 & Gary Condit 227 \\
\hline \multicolumn{4}{|l|}{ Bill Clinton } \\
\hline 2000 & G.W. Bush 910 & Bill Clinton 806 & Al Gore 530 \\
\hline 1999 & Bill Clinton 1319 & Lewinsky 344 & Hillary Clinton 293 \\
\hline 1998 & Bill Clinton 1712 & Lewinsky 332 & Kenneth Starr 139 \\
\hline 1997 & Bill Clinton 810 & O.J. Simpson 260 & Al Gore 103 \\
\hline 1996 & Bob Dole 838 & Bill Clinton 655 & O.J. Simpson 376 \\
\hline 1995 & Bill Clinton 338 & O.J. Simpson 145 & Newt Gingrich 103 \\
\hline 1994 & Bill Clinton 556 & Ted Kennedy 87 & Dan Quayle 56 \\
\hline $1993 *$ & Bill Clinton 761 & Ross Perot 100 & Al Gore 97 \\
\hline \multicolumn{4}{|l|}{ George H.W. Bush } \\
\hline 1992 & G.H.W. Bush 608 & Bill Clinton 423 & Dan Quayle 357 \\
\hline 1991 & Saddam Hussein 160 & Dan Quayle 150 & G.H.W. Bush 111 \\
\hline 1990 & Dan Quayle 162 & G.H.W. Bush 147 & Saddam Hussein 137 \\
\hline $1989 *$ & G.H.W. Bush 143 & Dan Quayle 135 & Ronald Reagan 79 \\
\hline \multicolumn{4}{|c|}{$\begin{array}{l}\text { *Presidents do not take office until Jan. } 20 . \\
\text { Note: The data include the jokes about public affairs and public figures from the monologues of the } \\
\text { late night television programs: "Late Night” with David Letterman, “The Tonight Show" hosted by } \\
\text { Johnny Carson and Jay Leno, and (from } 1993 \text { on) Conan O’Brien. The 1998-2001 data also include } \\
\text { the jokes of Bill Maher. The 1990-1994 data also include the jokes of Arsenio Hall. The } 1993 \text { data } \\
\text { also include the jokes of Jon Stewart. }\end{array}$} \\
\hline
\end{tabular}

\section{Conclusion}

When the president is not serving all that visibly as commander in chief, news coverage is consistently more negative than positive. As shown in the data, the first years of three recent presidents were quite negative, regardless of which party controlled the White House. But when an international crisis strikes, the media coverage is notably more positive, even if the president's actions are controversial. The evidence here suggests that presidents have a far greater ability to shape the county's political discussion than any other single actor, but that relative influence does not guarantee positive news coverage unless circumstances have created an international 
crisis. When there is an international crisis, though, even the number of latenight jokes about the president declines.

Although some of George W. Bush's partisans may claim he has been subject to a particularly harsh media treatment, the evidence here suggests he was generally treated about the same by reporters as were Clinton and Reagan, though perhaps less positively in some cases than his father. The key periods where Bush's coverage were distinctly more negative than his predecessors were perhaps as much a result of external factors as any alleged media bias. In early 2001, when the Supreme Court's ruling was still an open wound for many of Bush's critics, reporters found many people willing to give critical sound bites. After 9/11 and during the Iraq War of 2003, those critics were silenced, at least until after the occupation was underway (Entman 2004). The Bush team's efforts at spin seemed most effective during crises.

Bush's media strategy was marked by two general trends, ones likely to be replicated by future administrations - whether those administrations wish to follow Bush's media management style or not. Bush tried to maximize his influence by focusing on his commander in chief responsibilities, and by doing so help to silence dissent and cow his congressional critics. Despite the lack of convincing evidence of the utility of "going public," presidents continue to do so. Going public as commander in chief is likely to be a key strategy employed by future presidents, if for no other reason than the international environment involves a number of challenges for Bush's successor, be they in Iraq, in Afghanistan, in Pakistan, in North Korea, in Iran, or in the threatened states of the former Soviet Union. In such a chaotic international environment, it will be hard for a president to focus on domestic matters. The next president is going to have to spend a lot of time serving as commander in chief, whether he wants to or not. In fact, the more positive media treatment a president receives during periods of international instability may encourage future presidents to emphasize that part of the White House portfolio to the public and to Congress, even if international tempers cool in the years ahead.

The next president may find it difficult, though, to convince Congress to be as docile as it was during the Bush years. Republicans did little investigating of the Bush administration during their years in the majority, and the Democrats remained sufficiently scared of debating Bush over national security that they made little progress in investigating the administration during the years of opposition party control of Congress. The legislative branch has a history of asserting itself against subsequent presidents after being overrun by war-time presidents - and a revived Congress may be more assertive against the next president (cf., Woodward 1999). But, given the executive branch's media advantages, it remains to be seen how even an 
angry Congress can reframe political issues counter to the executive's preferences, particularly over international matters (Farnsworth and Lichter 2006).

The second general trend in Bush's media strategy involved an extreme "short-term-itis" in news management. While presidents have long sought to win control of the news cycle, things have changed a great deal since winning the news cycle meant having a good night on the evening news. The modern 24/7 media management system, one peppered with friendly reporters and harsh critics in the cable and online environments, tempt White House staffers to try to win the news cycle minute-by-minute. By failing to take more of a long-term perspective, the Bush administration has offered short-term goodies like tax cuts, but at devastating long-term costs to the national debt (Farnsworth 2009). The short-term gains of a "mission accomplished" moment come at the long term costs of an occupation of Iraq that turned out to be far worse than advertised, with many painful consequences. Along these same lines, Clinton's short-term physical pleasures and the subsequent televised denials of his misbehavior cost him dearly during his year-long impeachment scandal (Berman 2001).

Of course, elections are won in the short-term. Bush's intense public focus on the War on Terror clearly helped create a political discourse framework that favored the Republicans in 2002 and 2004. But that same framework also probably undermined the GOP's chances in 2006, as the occupation's duration angered many voters (Balz and Cohen 2007; Ceaser and Busch 2005).

Bush's mediated presidency demonstrates the limitations of trying to use the commander-in-chief role of the president to secure public support and passage of the president's agenda in other areas. The Iraqi occupation did not help Bush when Hurricane Katrina blew ashore in New Orleans in 2005, nor did it help the president secure passage of top domestic legislative priorities during his second term, including the partial privatization of Social Security.

Future presidents, though, may be greatly tempted to follow the path blazed by Bush, and before that by Clinton and Reagan. All of them frequently focused on winning the news cycle at the expense of longer-term policy priorities. All of them faced days of reckoning eventually-but primarily after they had been re-elected. On balance, though, practical politicians in the future likely will find this an acceptable trade-off, as previous presidents have.

All three presidents found that focusing on media management paid dividends in political support and deference from other political actors, at least in the early going. But such a strategy appears destined to be a stop-gap measure. The over-promising and under-delivering that seems to mark the 
modern mediated presidency does not seem likely to disappear anytime soon, particularly given the siren-song of short-term media management advantages for the White House.

\section{REFERENCES}

Baker, Nancy V. 2002. The Impact of Anti-Terrorism Policies on Separation of Powers: Assessing John Ashcroft's Role. Presidential Studies Quarterly 32(4):765-778.

Baker, Peter. 2007. General Is Front Man for Bush’s Iraq Plan. Washington Post, February 7.

Balz, Dan, and Jon Cohen. 2006. Independent Voters Favor Democrats by 2 to 1 in Poll. Washington Post, October 24.

Berman, William C. 2001. From the Center to the Edge: The Politics and Policies of the Clinton Presidency. Lanham, MD: Rowman and Littlefield.

Bonner, Raymond, and Jane Perlez. 2007. British Report Criticizes U.S. Treatment of Terror Suspects. New York Times, July 28.

Broder, John M. 2006. Democrats Take Senate: Concession in Virginia Completes Midterm Sweep. New York Times, November 10.

Brody, Richard A. 1991. Assessing the President: The Media, Elite Opinion, and Public Support. Stanford, CA: Stanford University Press.

Burns, James MacGregor, and Susan Dunn. 2001. The Three Roosevelts: Patrician Leaders Who Transformed America. New York: Atlantic Monthly Press.

Burns, John. F, Sabrina Tavernise, and Marc Santora. 2007. U.S. and Iraqis Are Wrangling over War Plans. New York Times, January 15.

Ceaser, James, and Andrew Busch. 2005. Red over Blue. Lanham, MD: Rowman and Littlefield.

Chandrasekaran, Rajiv. 2006. Imperial Life in the Emerald City: Inside Iraq's Green Zone. New York: Knopf.

Cook, Corey. 2002. The Contemporary Presidency: The Permanence of the 'Permanent Campaign': George W. Bush’s Public Presidency. Presidential Studies Quarterly 32(4):753-764.

Cronin, Thomas E., and Michael A. Genovese. 2004. The Paradoxes of the American Presidency, 2nd ed. New York: Oxford University Press.

Dallek, Robert. 2007. Nixon and Kissinger: Partners in Power. New York: HarperCollins.

Dimock, Michael. 2004. Bush and Public Opinion. In Considering the Bush Presidency, eds. Gary Gregg II and Mark J. Rozell. New York: Oxford.

Easton, Nina, et al. 2004. On the Trail of Kerry’s Failed Dream. Boston Globe, November 14.

Edwards, George C. III. 2006. The Illusion of Transformational Leadership. Paper delivered at the annual meeting of the American Political Science Association, Philadelphia, September 1.

Edwards, George C. III. 2003. On Deaf Ears: The Limits of the Bully Pulpit. New Haven, CT: Yale University Press.

Edwards, George C. III. 2004. Riding High in the Polls: George W. Bush and Public Opinion. In The George W. Bush Presidency: Appraisals and Prospects, eds. Colin Campbell and Bert A. Rockman. Washington, DC: CQ Press. 
Entman, Robert M. 2004. Projections of Power: Framing News, Public Opinion, and U.S. Foreign Policy. Chicago: University of Chicago Press.

Farnsworth, Stephen J. 2009. Spinner in Chief: How Presidents Sell Their Policies and Themselves. Boulder, CO: Paradigm.

Farnsworth, Stephen J., and S. Robert Lichter. 2006. The Mediated Presidency: Television News and Presidential Governance. Lanham, MD: Rowman and Littlefield.

Fisher, Louis. 2004. The Way We Go to War: The Iraq Resolution. In Considering the Bush Presidency, eds. Gary Gregg II and Mark J. Rozell. New York: Oxford University Press.

Frum, David. 2003. The Right Man: The Surprise Presidency of George W. Bush. An Inside Account. New York: Random House.

Gilbert, Robert E. 1989. President versus Congress: The Struggle for Public Attention. Presidential Studies Quarterly 16(3):83-102.

Gordon, Michael R. 2003. Basra Offers a Lesson on Taking Baghdad. New York Times, April 3.

Graber, Doris. 2006. Mass Media and American Politics, 7th ed. Washington, DC: CQ Press.

Gregg, Gary L. 2004. Dignified Authenticity: George W. Bush and the Symbolic Presidency. In Considering the Bush Presidency, eds. Gary Gregg II and Mark J. Rozell. New York: Oxford University Press.

Grossman, Michael B., and Martha Joynt Kumar. 1981. Portraying the President. Baltimore, MD: Johns Hopkins University Press.

Hall, Jim. 2001. Online Journalism: A Critical Primer. London: Pluto Press.

Han, Lori Cox. 2001. Governing from Center Stage: White House Communication Strategies during the Television Age of Politics. Cresskill, NJ: Hampton Press.

Hess, Stephen. 1981. The Washington Reporters. Washington, DC: Brookings Institution.

Hess, Stephen. 1986. The Ultimate Insiders: U.S. Senators in the National Media. Washington, DC: Brookings Institution.

Hess, Stephen. 1991. Live from Capitol Hill! Washington, DC: Brookings Institution.

Hess, Stephen. 1996. Presidents and the Presidency. Washington, DC: Brookings Institution.

Isikoff, Michael. 2000. Uncovering Clinton: A Reporter's Story. New York: Three Rivers Press.

Johnston, David, and Jim Rutenberg. 2007. At the Libby Trial, Hints of Intrigue and Betrayal. New York Times, January 25.

Kassop, Nancy. 2003. The War Power and Its Limits. Presidential Studies Quarterly 33:3, 509-29.

Kernell, Samuel. 2007. Going Public: New Strategies of Presidential Leadership, 4th ed. Washington, DC: CQ Press.

Klein, Joe. 2002. The Natural: The Misunderstood Presidency of Bill Clinton. New York: Doubleday.

Kumar, Martha Joynt. 2001. The Office of the Press Secretary. Presidential Studies Quarterly 31(2):296-322.

Kumar, Martha Joynt. 2003. The Contemporary Presidency: Communications Operations in the White House of President George W. Bush : Making News on His Terms. Presidential Studies Quarterly 33(2):366-393.

Kurtz, Howard. 1994. Media Circus: The Trouble with America's Newspapers. New York: Times Books / Random House.

Kurtz, Howard. 1998. Spin Cycle: Inside the Clinton Propaganda Machine. New York: Free Press. 
Kurtz, Howard. 2007. Journalist Forced to Reveal Her Methods. Washington Post, January 31.

Lichtblau, Eric, and David Johnston. 2007. Court to Oversee U.S. Wiretapping in Terror Cases. New York Times, January 18.

Lichter, S. Robert, and Daniel Amundson. 1994. Less News Is Worse News: Television News Coverage of Congress. In Congress, the Press, and the Public, eds. Thomas E. Mann and Norman Ornstein. Washington, DC: American Enterprise Institute and Brookings Institution.

Lichter, S. Robert, and Stephen J. Farnsworth. 2003. Government In and Out of the News. A Report to the Council for Excellence in Government. Washington, DC: Center for Media and Public Affairs.

Lindsay, James M. 2003. Deference and Defiance: The Shifting Rhythms of ExecutiveLegislative Relations in Foreign Policy. Presidential Studies Quarterly 33(3):530546.

Lowi, Theodore J. 1985. The Personal President: Power Invested, Promise Unfulfilled. Ithaca, NY: Cornell University Press.

Mann, Thomas E., and Norman J. Ornstein. 2006. The Broken Branch: How Congress Is Failing America and How to Get It Back on Track. New York: Oxford University Press.

McClellan, Scott. 2008. What Happened: Inside Bush's White House and Washington's Culture of Deception. New York: Public Affairs.

Milbank, Dana. 2004. The Administration versus the Administration. Washington Post, June 29.

Milkis, Sidney. 2006. The Presidency and Political Parties. In The Presidency and the Political System, 8th ed., ed. Michael Nelson. Washington, DC: CQ Press.

Miroff, Bruce. 2006. The Presidential Spectacle. In The Presidency and the Political System, 8th ed., ed. Michael Nelson. Washington, DC: CQ Press.

Mooney, Chris. 2004. Did Our Leading Newspapers Set Too Low a Bar for a Preemptive Attack? Columbia Journalism Review, March-April.

Nagourney, Adam, and Janet Elder. 2006a. Only 25\% in Poll Voice Approval of Congress. New York Times, September 21.

Nagourney, Adam, and Janet Elder. 2006b. Poll Shows Foley Case Is Alienating Public from Congress. New York Times, October 10.

Nelson, Michael. 2003. Evaluating the Presidency. In The Presidency and the Political System, 7th ed., ed. Michael Nelson. Washington, DC: CQ Press.

Orkent, Daniel. 2004. Weapons of Mass Destruction? Or Mass Distraction? New York Times, May 30.

Pew Research Center for the People and the Press. 2000. Some Final Observations on Voter Opinions. December 21.

Pfiffner, James P. 2004a. The Character Factor: How We Judge America's Presidents. College Station: Texas A\&M University Press.

Pfiffner, James P. 2004b. Introduction: Assessing the Bush Presidency. In Considering the Bush Presidency, eds. Gary Gregg II and Mark J. Rozell. New York: Oxford University Press.

Quirk, Paul. 2006. Presidential Competence. In The Presidency and the Political System, 8th ed., ed. Michael Nelson. Washington, DC: CQ Press.

Rieff, David. 2003. Blueprint for a Mess. New York Times Magazine, November 2.

Risen, James, and Eric Lichtblau. 2007. Concerns Raised on Wider Spying under New Law. New York Times, August 19. 
Rozell, Mark. 1994. Press Coverage of Congress, 1946-1992. In Congress, the Press, and the Public, eds. Thomas E. Mann and Norman Ornstein. Washington, DC: American Enterprise Institute and Brookings Institution.

Rutenberg, Jim. 2007. Edwards Campaign Tries to Harness Internet. New York Times, August 1.

Rutenberg, Jim, and David Cloud. 2006. Bush, Facing Dissent on Iraq, Jettisons 'Stay the Course.' New York Times, October 24.

Shane, Scott. 2007c. Former Press Secretary Dispels Many Illusions. New York Times, January 30.

Shane, Scott, and Neil Lewis. 2007. Bush Commutes Libby Sentence, Saying 30 Months 'Is Excessive.' New York Times, July 3.

Shane, Scott, and Adam Liptak. 2006. Shifting Power to a President. New York Times, September 30.

Shanker, Thom. 2007. New Strategy Vindicates Ex-Army Chief Shinseki. New York Times, January 12.

Skocpol, Theda. 1997. Boomerang: Health Care Reform and the Turn against Government. New York: Norton.

Tapper, Jake. 2001. Down and Dirty: The Plot to Steal the Presidency. Boston: Little, Brown.

Tapper, Jake. 2002. Down and Dirty, Revisited: A Postscript on Florida and the News Media. In Overtime: The Election 2000 Thriller, ed. Larry Sabato. New York: Longman.

Tulis, Jeffrey K. 1987. The Rhetorical Presidency. Princeton, NJ: Princeton University Press.

VandeHei, Jim. 2005. Bush Paints His Goals as 'Crises.' Washington Post, January 8.

Waterman, Richard W., Robert Wright, and Gilbert St. Clair. 1999. The Image-Is-Everything Presidency. Boulder, CO: Westview.

Zernike, Kate. 2006. Bush's Use of Authority Riles Senator. New York Times, June 28. 